\title{
PAPAN LOMPAT KELINCI SEBAGAI MEDIA MENGEMBANGKAN KEMAMPUAN MEMAHAMI KONSEP ANGKA 10-20 PADA ANAK USIA 5-6 TAHUN DI TK LABSCHOOL UMC
}

\author{
CUCU SOPIAH \\ PG-PAUD Universitas Muhammadyah Cirebon. Kampus 2 Jl.Fatahilah \\ Watubelah Cirebon \\ E-Mail: sofirindu@ gmail.com
}

\begin{abstract}
Problems in this study there are still some children aged 5-6 years in UMC Lab school Kindergarten, experiencing confusion in understanding the concept of numbers 10-20, some children can not mention the symbol of the numbers 10-20 of the largest and the smallest in sequence, and can not mention the number 10-20 symbol with the number of objects randomly. The goal is to improve the ability to recognize the concept of numbers 10-20 in UMC Lab school Kindergarten. Preliminary observations obtained data ability to recognize the concept of numbers 10-20 in children Group B Kindergarten Lab school UMC reaches $20 \% \mathrm{BSH}$ value. Cycle I is given action with rabbit jump board media, so the ability to understand the concept of 10-20 can increase with the acquisition of $25 \% \mathrm{BSH}$ value. The second cycle is $80 \% \mathrm{BSH}$ and $3 \% \mathrm{BSB}$. At the end of the third cycle there was a significant increase of $77 \% \mathrm{BSH}$ value and $8 \% \mathrm{BSB}$ value. So the average success rate of Group B Labschool UMC Kindergarten students in the ability to recognize the concept of numbers 10-20 is very satisfactory.
\end{abstract}

Keywords: Rabbit Jump Board, Concept of Figures

\begin{abstract}
Abstrak: Masalah dalam penelitian ini masih ada beberapa anak usia 5-6 tahun di TK Labschool UMC, mengalami kebingungan dalam memahami konsep angka 10-20, sebagian anak belum dapat menyebutkan lambang angka 10-20 dari yang terbesar maupun yang terkecil secara berurutan, serta belum dapat menyebutkan lambang angka 10-20 dengan jumlah benda secara acak. Tujuannya untuk meningkatkan kemampuan mengenal konsep angka 10-20 di TK Labschool UMC. Observasi awal diperoleh data kemampuan mengenal konsep angka 10-20 pada anak Kelompok B TK Labschool UMC mencapai 20\% nilai BSH. Siklus I diberikan tindakan dengan media papan lompat kelinci, sehingga kemampuan memahami konsep angka 10-20 dapat meningkat dengan perolehan nilai $\mathrm{BSH}$ $25 \%$, Siklus ke-II terjadi peningkatan yakni $40 \%$ BSH, dan nilai BSB 3\%. Di akhir siklus ke III ada peningkatan yang signifikan mencapai $77 \%$ nilai BSH dan 8\% nilai BSB. Sehingga tingkat keberhasilan rata-rata anak Kelompok B TK Labschool UMC dalam kemampuan mengenal konsep angka 10-20 sangat memuaskan.
\end{abstract}

Kata Kunci: Papan Lompat Kelinci, Konsep Angka 
PENDAHULUAN

Pendidikan Anak Usia dini merupakan Pendidikan yang Krusial, karna pada masa ini terbentuknya dasar kemampuan penginderaan, sosial emosi, bahasa dan kemampuan berfikir. Usia dini disebut sebagai masa kritis dan sensitif yang akan menentukan sikap, nilai, dan pola perilaku seseorang dikemudian hari dimasa kritis potensi dan kecenderungan serta kepekaan seseorang akan mengalami aktualisasi apabila mendapat rangsangan yang tepat. Salah satu aspek yang harus dibangun sejak masa usia dini adalah pembentukan aspek keterampilan berfikir khususnya kemampuan berhitung permulaan yang identik dengan pengenalan konsep berhitung

Matematika permulaan diperlukan untuk mengembangkan pengetahuan dasar agar anak siap mengikuti jenjang sekolah berikutnya. Pada jenjang yang baru dikenalnya Anak usia dini akan dihadapkan dengan tuntutan di sekolah agar dapat belajar dengan cepat dalam mengenal matematika, oleh karna itulah banyaknya kekhawatiran orang tua saat menyekolahkan anaknya pada lembaga formal dan informal agar dapat membaca, menulis dan berhitung.

Kekhawatiran inilah yang dirasakan oleh lembaga PAUD diIndonesia agar bisa membekali anak usia dini dengan kemampuan membaca dan berhitung dengan cara yang menyenangkan yakni dengan bermain.

Pendekatan bermain merupakan sebuah strategi atau cara yang digunakan oleh guru dalam memasukan pembelajaran yang ingin dicapai. Salah satu pembelajaran yang ingin dikembangkan untuk anak kelompok B jenjang usia 5-6 tahun adalah kemampuan kognitif anak yakni anak dapat menguasai konsep angka 10-20.
Konsep angka dapat difahami anak melalui bermain menghadirkna objek nyata, hal tersebut dikarnakan pola berfikir anak usia dini masih berfikir pra oprasioanal. Perkembangan tersebut juga sesuai dengan pandangannya Piaget, mengemukakan bahwa perkembangan kognitif anak usia 7-9 berada pada masa pra operasional, masa ini mencakup kemampuan untuk memahami konsep bilangan dan angka, mampu menghubungkan dan membandingkan objek, peristiwa dan orang-orang berdasarkan hubungan sebab akibat atau ukuran, bentuk dan jumlah, memahami bahwa simbol-simbol tertentu mengandung arti dan bermakna (Papalia dan Olds dalam Jamaris, 2005: 181)

Penguasaan konsep matematika awal akan mudah dipahami anak apabila kegitan penguasaan konsep matematika tersebut disajikan melalui media yang menarik dan menyenangkan.

Konsep angka pada anak usia dini akan mudah untuk dipahami apabila konsep yang disajikan kongkrit. Kongkrit disini adalah dapat dirasakan kehadirannya oleh anak dalam bentuk yang nyata, sehingga anak mudah untuk memahaminya

Namun dari hasil observasi yang dilakukan di kelompok B TK Labschool UMC, kemampuan mengenal konsep angka 10-20 masih rendah. Di Lapangan terlihat anak masih mengalami kebingungan dalam memahami konsep angka 10-20, sebagian anak belum dapat menyebutkan lambang angka 10-20 dengan jumlah benda secara berurutan dari yang terkecil sampai yang terbesar, anak belum dapat menyebutkan lambang angka 10-20 dengan jumlah benda secara berurutan dari yang terbesar sampai yang terkecil, dan anak masih belum dapat menyebutkan lambang angka 10-20 dengan jumlah benda secara acak.

Pemahaman konsep tersebut belum dapat dipfahami dikarnakan pola berfikir 
anak usia dini masih dalam tahap praoprasional. Hal tersebut telah diungkapkan oleh Piaget (dalam Suyanto, 2005: 53) bahwa perkembangan kognitif anak berada pada tahap pra operasional. Thapan ini membutuhkan kreatifitas guru untuk menghadirkan bentuk yang kongkrit bagi anak dari semua benda yang akan dipelajarinya, anak dapat merasakan secara kongkrit untuk meraba, melihat merasakan kehadiran, warna dan bentuk benda dengan semua sensornya, sehingga anak tidak dipaksakan untuk berfikir abstrak dengan menghayal bentuk nyata dari setiap benda.

Cara berfikir kongkrit inilah yang menjadi kekhasan anak usia dini dalam memahami konsep, sehingga anak usia dini masih membutuhkan simbol-simbol yang melambangkannya dengan pengalaman langsung yang dirasakan oleh anak.

Pengalaman langsung yang bisa langsung dirasakan oleh anak yakni melalui bermain dengan media yang menyenangkan salah satunya yaitu permainan dengan media papan lompat kelinci yang menyenangkan.

Media Permainan Papan lompat kelinci mengajak anak untuk ikut serta bermain merasakan permainan dengan cara ikut berperan langsung dalam permainannya. Contohnya saat anak ikut bermain dengan media papan lompat kelinci anak akan mengocok angka dalam kotak serta melihat simbol angka dalam gulungan kertas, sehingga anak akan mencoba mencari dan mencocokan angka yang diperolehnya dengan melompat pada papan kelinci melompat yang bertuliskan angka dan jumlah benda yang sesuai. Sehingga dari permainan tersebut anak akan belajar menemukan konsep angka mulai dari 10-20 sesuai dengan jumlah benda yang tertera di papan lompat kelinci tersebut.

Alasannya penulis membuat media papan lompat kelinci yakni media tersebut tidak ada dipasaran sehingga menjadi faktor yang mempengaruhi peneliti ingin melakukan penelitian tersebut. Dalam penelitian ini, penulis akan meneliti bagaimana pengembangan materi pembelajaran dengan pendekatan media papan lompat kelinci untuk meningkatkan kemampuan pemahaman konsep angka 1020 .

Tujuan yang ingin dicapai dalam penelitian ini adalah untuk meningkatkan kemampuan anak mengenal konsep angka 10-20 melalui media papan lompat kelinci, Untuk mengetahui besarnya peningkatan kemampuan pemahaman konsep angka 1020 anak khususnya melalui media papan lompat kelinci di TK Labschool UMC.

\section{KAJIAN TEORI}

Konsep adalah ide (abstrak) yang dapat digunakan atau memungkinkan seseorang untuk mengelompokkan atau menggolongkan sesuatu objek. Soedjadi (2007) mendefinisikan konsep adalah ide abstrak yang digunakan untuk mengadakan klasifikasi atau penggolongan yang pada umumnya dinyatakan dengan suatu istilah atau rangakaian kata. Sedangkan menurut wardani (2008) Suatu konsep biasa dibatasi dalam suatu ungkapan yang disebut definisi.

Woodruff (dalam Rahman, 2009) telah mengidentifikasi 3 macam konsep yaitu (1) konsep proses: tentang kejadian atau perilaku dan konsekuensi-konsekuensi yang dihasilkan bila terjadi, (2) konsep struktur: tentang objek, hubungan atau struktur dari beberapa macam, dan (3) konsep kualitas: sifat suatu objek atau proses dan tidak mempunyai eksistensi yang berdiri sendiri. Pemahaman konsep diperoleh melalui proses belajar. Sedangkan belajar merupakan proses kognitif yang melibatkan tiga proses yang berlangsung hampir bersamaan. Ketiga proses tersebut adalah : (1) memperoleh informasi baru, (2) transformasi informasi, dan (3) menguji relevansi dan ketetapan pengetahuan. Dahar (dalam Syamri, 2010).

Sedangkan angka menurut Tadkirotun (2012) adalah lambang atau simbol yang merupakan suatu objek yang 
terdiri dari angka-angka. Sebagai contoh bilangan 10, dapat ditulis dengan dua buah angka (double digits) yaitu angka 1 dan angka 10). Konsep angka menurut Tim Kreatif Cikal Aksara (2011) adalah objek matematika yang digunakan untuk menghitung dan mengukur.

$$
\text { pendapatnya Copley (2001:47) }
$$

mengatakan angka atau bilangan adalah lambang atau simbol yang merupakan suatu objek yang terdiri dari angka- angka. Sebagai contoh bilangan 10, dapat ditulis dengan dua buah angka (double digits) yaitu angka 1 dan angka 10).

Berdasarkan beberapa pendapat tersebut diatas maka dapat disimpulkan konsep angka 10-20 adalah gagasan makna simbol-simbol angka yang melambangkannya mulai dari angka 1 sampai dengan angka 20 bersama dengan pemahaman jumlah bendanya.

Media adalah Menurut Djamaroh (1995: 136) adalah alat bantu yang dapat dijadikan sebagai penyalur pesan guna mencapai tujuan pembelajaran, Sedangkan menurut Rudi Susilana (2009:6) media merupakan perantara sumber pesan dan penerima pesan. Menurut Sardiman dkk, (2006:7) media adalah segala sesuatu yang dapat digunakan untuk menyalurkan pesan dari pengirim ke penerima pesan sehingga proses belajar dapat terjadi.

Papan kelinci melompat adalah sebuh papan yang dibentuk sedemikian rupa terdapat gambar dan jumlah angka menyerupai bentuk salib dengan papan kotak tersusun horizontal kedepan sebanyak delapan papan kotak angka bergambar dan dua papan kotak angka tersusun menyamping kesamping dapat dimainnkan dengan cara melompat kelinci pada setiap kotak yang terlempar gacoan.

Berdasarakan uraian diatas maka dapat disimpulkan media papan kelinci melompat adalah media pembelajaran berupa papan angka bergambar yang dapat dimainnkan dengan cara melompat kelinci pada setiap kotak yang terlempar gacoan.

\section{METODE}

Penelitian ini dilakukan dengan menggunakan metode penelitian tindakan kelass yang bersifat partisipatif dan kolaboratif. Lokasi penelitian di TK Labschool UMC. Waktu penelitian ini dilaksanakan bulan September 2017. Subjek penelitian ini berjumlah 18 anak terdiri dari laki-laki 8 anak dan perempuan 10 anak yang berusia 5-6 tahun. Tehnik pengumpul data dalam penelitian ini adalah melalui observasi dan dokumentasi. Perencanaan penelitian menggunakan metode penelitian tindakan model Kemmis dan Taggart dengan tiga siklus, setiap siklus mempunyai langkah-langkah: (1) Perencanaan, (2) Tindakan/ Acting, (3) Pengamatan/ Observing, (4) Refleksi atau hasil observasi. Berdasarkan Refleksi ini pula suatu perbaikan tindakan (replanning) selanjutnya ditentukan. Setiap siklus terdiri dari 2 kali pertemuan.

Adapun pengukuran kemampuan memahami konsep angka 10-20 dalam penelitian ini terdiri dari empat indikator yakni Anak dapat mengenal lambang angka 10-20 dengan jumlah benda, Anak dapat menyebutkan lambang angka 10-20 dengan jumlah benda secara berurutan dari yang terkecil sampai yang terbesar, Anak dapat menyebutkan lambang angka 10-20 dengan jumlah benda secara berurutan dari yang terbesar sampai yang terkecil, dan Anak dapat menyebutkan lambang angka 10-20 dengan jumlah benda secara acak.

Penilaian dilkukan dengan cara observassi partisipan dengan 4 kategori penilaian yakni nilai BB (Belum Berkembang), MB (Mulai Berkembang), BSH (Berkembng Sesuai Harapan) dan BSB (Berkembang Sangat Baik). Rencana Penilaian yang ditargetkan hanya pada 
indikator pencapaian BSH. Adapun pencapaian nilai BSB hanya diperoleh pada anak tertentu yang terlihat sanagat menonjol dari pada kemampuan anak yang lainnya.

\section{HASIL DAN PEMBAHASAN}

Sebelum penelitian dilaksanakan, kemampuan mengenal konsep angka 10-20 pada anak kelompok B TK Labschool UMC masih rendah. Hasil penelitian pra siklus menunjukan hasil perolehan nilai kemampuan mengenal konsep angka 10-20 belum berkembang mencapai $60 \%$, mulai berkembang $40 \%$ dan berkembang sesuai harapan mencapai $20 \%$.

Perolehan data di lapangan menunjukan kemampuan mengenal konsep angka 10-20 masih rendah. Sebagian anak belum dapat menyebutkan lambang angka 10-20 dengan jumlah benda secara berurutan dari yang terkecil sampai yang terbesar, anak belum dapat menyebutkan lambang angka 10-20 dengan jumlah benda secara berurutan dari yang terbesar sampai yang terkecil, dan anak masih belum dapat menyebutkan lambang angka 10-20 dengan jumlah benda secara acak.

Hasil observasi tersebut menunjukan bahwa, guru perlu meningkatkan kualitas pembelajaran dalam meningkatkan kemampuan mengenal konsep angka 10-20 pada anak kelompok B TK Labschool UMC. Untuk itu maka diperlukan langkah perbaikan pembelajaran dengan tindakan kelas yakni dengan menerapkan media pembelajaran papan lompat kelinci. Dengan pelaksanaan III Siklus yaitu siklus I dilaksanaka selama 2 hari yaitu tanggal 6 sampai 7 September 2017. Kemudian dilanjutkan dengan suklus II pada hari senin tanggal 11 sampai dengan selasa tanggal 12 September 2017. Dan siklus terakhir yang ke III dilaksanakan pada hari rabu tanggal 13 sampai kamis tanggal 14 september 2017.

\section{Deskrpisi Per Siklus}

\section{Siklus I}

Hasil evaluasi peningkatan kemampuan mengenal konsep angka 10-20 pada anak kelompok B TK Labschool UMC. Awal perbaikan siklus I, pertemuan ke satu reaksi perbaikan kemampuan mengenal konsep angka 10-20 belum menunjukan reaksi yang memuaskan, dimana anak masih terfokus untuk mengamati media.

Pertemuan ke-dua perbaikan kemampuan mengenal konsep angka 10-20 mulai menunjukan perbaikan yakni anak sudah mulai ada respon untuk bermain mengikuti permainan dengan media papan kelinci melompat. Sebagian anak sekitar $25 \%$ anak sudah dapat memahami konsep angka10-20, 40\% mulai berkembang dan $52 \%$ belum berkembang, hal tersebut dikarnakan anak masih terlihat bingung dan sulit untuk memahami konsep 10-20 berdasarkan empat indikator penilaian. Keterangan dapat dilihat di dalam diagram (1.A):

Diagram 1.A

(Kemampuan Memahami Konsep Angka 10-20 Melalui Papan Lompat Kelinci Pada Anak Usia 56tahun Di Tk Labschool)

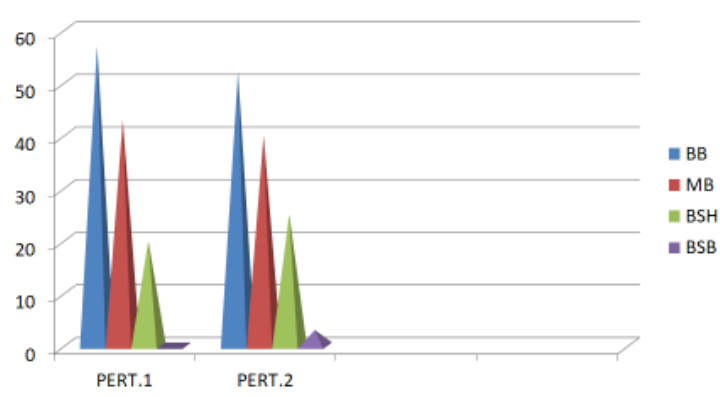

Siklus II

Hasil evaluasi kemampuan memahami konsep angka 10-20 pada anak kelompok B TK Labschool UMC pada akhir perbaikan siklus II kemampuan mengenal konsep angka 10-20 belum 
berkembang $13 \%$, mulai berkembang $63 \%$, berkembang sesuai harapan $40 \%$ dan berkembang sangat baik 3\%. Artinya kemampuan mengenal konsep angka 10-20 sudah mulai menunjukan perbaikan yang cukup baik, namun masih memerlukan penguatan dengan melakukan siklus ke III agar kemampuan memahami konsep angka 10-20 pada anak kelompok B TK Labschool UMC dapat dipahami oleh semua anak. Keterangan dapat dilihat di dalam diagram (1.B):

\section{Diagram 1.B}

(Kemampuan Memahami Konsep Angka 10-20 Melalui Papan Lompat Kelinci Pada Anak Usia 56tahun Di Tk Labschool)

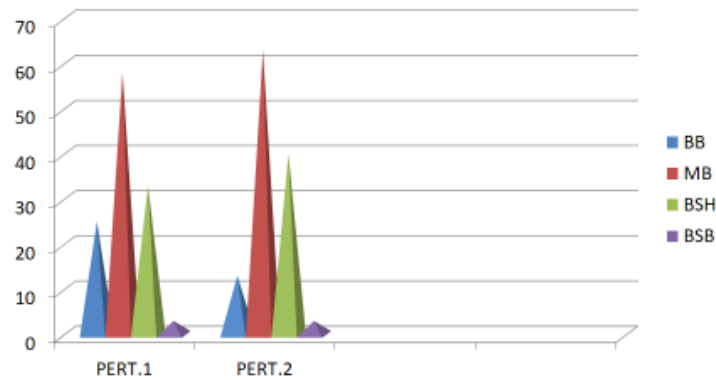

Siklus III

Peningkatan praktik mencuci tangan disiklus ketiga kemampuan memahami konsep angka 10-20, menunjukan peningkatan nilai akhir yang sangat memuaskan yakni $77 \%$. Hasil pencapaian persentasi tersebut dianggap sudah memenuhi dari target pencapaian indikator keberhasilan yang sudah ditargetkan sebelumnya.

Anak dapat mengenal lambang angka 10-20 dengan jumlah benda, Anak dapat menyebutkan lambang angka 10-20 dengan jumlah benda secara berurutan dari yang terkecil sampai yang terbesar, Anak dapat menyebutkan lambang angka 10-20 dengan jumlah benda secara berurutan dari yang terbesar sampai yang terkecil, dan Anak dapat menyebutkan lambang angka 10-20 dengan jumlah benda secara acak.

Hasil perolehan nilai kemampuan mengenal konsep angka 10-20 pada akhir siklus diperoleh nilai, belum berkembang tinggal 5\%, mulai berkembang 30\% berkembang sesuai harapan mencapai nilai
$77 \%$ dan berkembang sangat baik mencapai $8 \%$. Keterangan dapat dilihat di dalam diagram (1.3):

Diagram 1.C

(Kemampuan Memahami Konsep Angka 10-20 Melalui Papan Lompat Kelinci Pada Anak Usia 56tahun Di Tk Labschool)

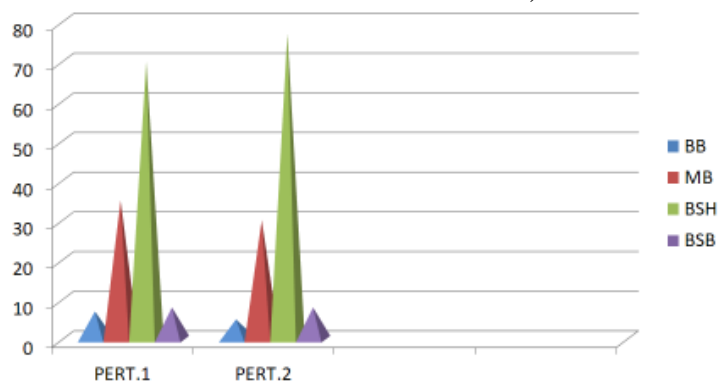

\section{Hasil Analisis Data}

Kemampuan memahami konsep angka 10-20 melalui media papan kelinci melompat pada kelompok B TK Labschool UMC dapat meningkat. Hal ini dapat dilihat bahwa sebelum menggunakan media papan kelinci melompat, perolehan nilai kemampuan mengenal konsep angka 10-20 belum berkembang mencapai $60 \%$, dan nilai Berkembang sesuai harapan masih rendah yakni $20 \%$, disiklus ke satu perolehan nilai $\mathrm{BSH} 25 \%$ dan siklus ke dua terjadi kenaikan nilai Berkembang sesuai harapan mencapai $40 \%$. Baru pada siklus ketiga terjadi kenaikan yang pesat mencapai nilai $77 \%$.

Adapun Nilai berkembang sangat baik diperoleh anak dari nilai diatas ratarata kelompok anak mencapai $8 \%$. Sehingga terbukti bahwa tindakan pemberian media papan kelinci melompat di TK Labschool UMC berhasil dapat meningkatkan kemampuan mengenal konsep angka 10-20. Keterangan tersebut dapat dilihat di dalam tabel dan diagram berikut:

Tablel 1.

(Kemampuan Memahami Konsep Angka 10-20 Melalui Papan Lompat Kelinci Pada Anak Usia 56tahun Di Tk Labschool)

\begin{tabular}{ccccc}
\hline SIKLUS & BB & MB & BSH & BSB \\
\hline Pra Siklus & $60 \%$ & $40 \%$ & $20 \%$ & $0 \%$ \\
\hline
\end{tabular}




\begin{tabular}{lcccc}
\hline Siklus I & $45 \%$ & 40 & $25 \%$ & $3 \%$ \\
\hline Silkus II & $13 \%$ & $63 \%$ & $40 \%$ & $3 \%$ \\
\hline Silkus II & $5 \%$ & $30 \%$ & $77 \%$ & $8 \%$ \\
\hline
\end{tabular}

Diagram 1.D

(Kemampuan Memahami Konsep Angka 10-20 Melalui Papan Lompat Kelinci Pada Anak Usia 56tahun Di Tk Labschool 1)

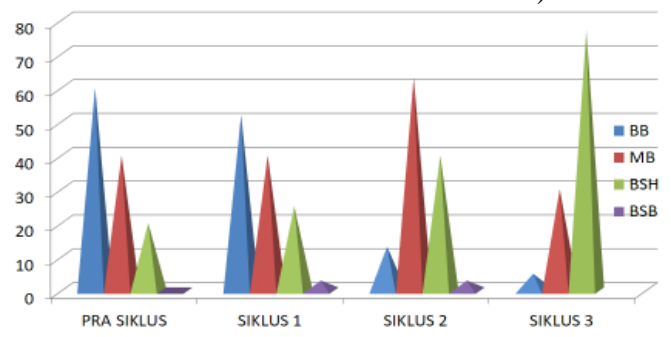

\section{KESIMPULAN}

Berdasarkan hasil analisis data yang diperoleh dalam penelitian ini dapat diambil kesimpulan kemampuan mengenal konsep angka 10-20 pada anak TK Labschool UMC melalui media papan kelinci melompat dapat ditingkatkan.

Hasil diperoleh adanya peningkatan praktik mencuci tangan pada anak PAUD TK Labschool UMC melalui media papan kelinci melompat dimana hal ini terlihat dengan adanya peningkatan dari pra siklus yakni perolehan nilai kemampuan mengenal konsep angka 10-20 yang sebelumnya perolehan nilai berkembang sesuai harapan masih rendah yakni $20 \%$, naik menjadi $77 \%$ pada siklus terakhir yaitu siklus ke tiga yang melebihi target pencapaian indicator keberhasilah yang sudah ditentukan sebelumnya yakni $75 \%$ Sehingga terbukti tingkat keberhasilan rata-rata anak pada kemampuan mengenal konsep angka 1020, sangat memuaskan.

Penelitian ini menunjukan bahwa penggunaan media papan kelinci melompat dapat meningkatkan kemampuan mengenal konsep angka 10-20 pada anak PAUD TK Labschool UMC.

\section{Daftar Pustaka}

Daryanto. 2011. Manajemen Pemasaran: Sari Kuliah. Bandung: Satu Nusa.

Djamaroh, Syaiful Bahri. 1995. Strategi Belajar Mengajar. Jakarta: Rineka Cipta

Copley, V Juanita. (2001). The Young Child and Mathematics.Washington :National Association for the Education of Young Children.

Jamaris, Martini. 2005. Pengembangan Multiple Intelligences dan Aplikasinya Melalui Pembelajaran Terpadu di Taman Kanak- Kanak. Jurnal Pandidikan dan Kebudayaan, No. 053, Tahun Ke-11. Jakarta: Badan Penelitian dan Pengembangan Departemen Pendidikan Nasional.

Rahman 2009.

"Pengertian Paradigma". Tersedia pada http://devirahman. wordpress.com/2009/04/24/pengertianparadigma/ (diakses tanggal 23 februari 2015).

Suyanto, Slamet. 2005. Konsep Dasar Pendidikan Anak Usia Dini. Jakarta: Direktorat Jenderal Pendidikan Tinggi Departemen Pendidikan Nasional.

Soedjadi. 2007. Masalah Kontekstual Sebagai Batu Sendi Matematika Sekolah. Depdiknas : UNESA

Tadkirotun, $\quad$ Musfiroh. 2012. Pengembangan Kecerdasan Majemuk. Tangerang : Universitas Terbuka.

Tim Kreatif Cikal Aksara. 2011.Latihan lengkap TK A dan TK B. Jakarta: Cikal Aksara. 
Tim Kreatif Cikal Aksara. 2011.Latihan lengkap TK A dan TK B. Jakarta: Cikal Aksara.

Syamri. 2010. "Pengertian Konsep". Tersedia Pada http: //id.shvoong.com/writing-and- speaking/ 2035426- pengertian-konsep/. (diakses tanggal 23 februari, 2015).

Susilana, Rudi. Riyana, Cepi. 2009. Media Pembelajaran: Hakikat,

Pengembangan, Pemanfaatan, dan Penilaian. Bandung: CV Wacana Prima.

Wardhani, Sri. (2008). Analisis SI dan SKL Mata Pelajaran Matematika SMP/MTs untuk Optimalisasi Tujuan Mata Pelajaran Matematika. Yogyakarta: Depdiknas 